\title{
MIGRATION AND IMMIGRANTS AS THE "USUAL SUSPECTS" OF EUROPEAN INSECURITY
}

\author{
Bülent Sarper Ağır, PhD. \\ Adnan Menderes University, Faculty of Economics, \\ The Department of International Relations \\ E-mail: bsagir@adu.edu.tr
}

\begin{abstract}
Recent terrorist attacks in many cities of Europe such as London, Madrid, Paris, Nice and Brussells lead to strenghtening of the anti-immigrant attitudes in European public opinion and political life. Under these circumstances, migration and migrants with their security implications are highly politicized and even securitized issues for the European Union and the countries of Europe through political discourses, bureuacratic practices and media visuals. So, migrationrelated issues are increasingly integrated into discourses and policies arranging domains of insecurity. Migration was largely considered as a contribution to the economic reconstruction of Europe until the 1990 s. However, in the last couple of decades, it has been perceived as a security threat. This perception is constructed by combinig migration with socio-economic problems, crime, cultural problems and finally terrorism. Therefore, migration, immigrants and asylum-seekers are now the objects of securitization process in Europe. They are portrayed as a threat to the cultural identity, welfare state and internal security of the West and the EU. On the other hand, in order to avoid the contradiction in terms of main values of the EU, the struggle against the migration issue is required to re-emphasise the liberal practices by preserving identical differences in a cosmopolitan policy. Because, emphasizing restrictions and control implies a negative portrayal of groups of immigrants. Such a policy risks sustaining public expressions of racism and xenophobia in the present political context. This paper argues that measures taken by the individual countries of Europe and the EU for the migration and immigrants should not be in contradiction with main values such as multiculturalism, human rights, democracy and inclusive social structure on which the $\mathrm{EU}$ is based on.
\end{abstract}

Keywords: Security, Securitization, Migration, Immigrants, Europe 


\section{Introduction}

Neighbour countries and regions who are engaged in violent conflict, weak states where organised crime and terrorism flourish, deep socio-economic deprivation of societies and population growth on its borders all pose security problems for Europe. These considerations reveal that there is a need to reevaluate the European Union's (EU) security perceptions in the new security environment. In this direction, the EU has been trying to integrate the human security concept into its security policies during $2000 \mathrm{~s}$ as a "normative power" of global politics. These efforts of the EU reflect the changing security environment by recognizing the shift from a merely military conception of security to the inclusion of non-traditional security threats (Ağır, 2015: 367).

In this respect, migration, immigrants and asylum represent one of the phenomena in relation to which sense of insecurity is articulated. Previously migration was considered as economically motivated action and blessed for its contribution for the economically reconstruction of Europe. However, nowadays it is perceived as a threat to European society. This perception is constructed by connecting the migration and immigrants with issues such as criminal activities, socio-economic problems and terrorism through political discourses, institutional bureaucratic practices and media coverage. In political and academic debates and in everyday conversations immigrants and refugees are often portrayed as disturbing normal ways of life (Huysmans, 2006: 45), and contribute to securitization process of the migration. Some assumptions such as borderless Europe can be abused by criminals and irregular migrants have led to acceleration of securitization process of the migration. Thus, policy makers in Europe have increasingly associated migration to security and sought to meet this 'threat' through 'control' and 'surveillance' methods.

Recent terrorist attacks in many cities of Europe such as London, Madrid, Paris, Nice and Brussells have led to strenghtening of the anti-immigrant attitudes and tendencies in European public opinion and political life. In this regard, populist and far rightist social movements and political parties have increased their support in their own societies. Under these circumstances, migration and immigrants with their security implications are highly politicized and even securitized issues for the EU and the countries of Europe. So, migration-related issues are increasingly integrated into discourses and policies arranging domains of insecurity. Migration as a security threat functions as a condition that triggers and/or sustains the mobilization of security agencies, political rhetoric of insecurity, and popular perceptions of danger.

In the last couple of decades, migration and immigrants have been perceived as a security threat. This perception is constructed by combinig migration with socio-economic problems, organized crime, cultural problems and finally terrorism. Therefore, migration, immigrants and asylum-seekers are now the objects of securitization process in Europe. They are portrayed as a threat to the cultural identity, welfare state and internal security of the West and the EU. On the other hand, in order to avoid the contradictions in terms of main political values of the EU, the struggle against the migration issue is required to re-emphasise the liberal practices by preserving identical differences in a cosmopolitan policy. This article argues that measures taken by the individual countries of Europe and the EU for the migration should not be in contradiction 
with main values such as multiculturalism, human rights, democracy and inclusive social structure on which the $\mathrm{EU}$ is based on.

\section{Securitization of Migration: Discourse, Practices and Images}

International migration was associated with security in the 1990s more than it was in the 1980 s. Addressing migration in such negative terms, according to Ole Wæver, has become more common in the post-Cold War world, "where the concerns about military security are being replaced by concerns about societal security, in which migration is the key" (Wæver, 1993: 19). 'Societal security' refers to security situations in which societal developments, in this article migration, threaten identity of a people, rather than the state as a sovereign political organization. Security needs and problems of social groups in terms of their identities are conceptualized by societal security concept.

However, when it comes to the $2000 \mathrm{~s}$, migration is re-linked to military security due to receiving states' concerns about several security problems. These problems include drug trafficking, organized crime, global mafias, international money laundering, urban violence, Islamic radicalism, terrorism supported by immigrant sending countries, huge influxes of refugees, and attacks on national identity due to the presence of 'alternative behaviors' of immigrants (Bigo, 2001: 122). In terms of national identity issue, immigrants are also formulated as 'bearers of multiple social threats'. According to Tsoukala, addressing immigrants as such is formulated by politicians, officials, and the media, as a result of which immigrants became transformed into a threat to societal security (Tsoukala, 2005: 163). In this respect, immigrants have been characterized as 'other' and 'stranger' as a source of security threat to 'our' borders, jobs, housing as well as states' values, collective identities, and cultural homogeneity (Faist, 2002: 7).

The starting point for the traditional security conception about the relationship between migration and security is related with the threat assessment introduced by migration and immigrants to the national security of states. Because traditional security conception to migration gives attention to national security interests of states as referents of security. In this context, immigrants are portrayed as a security threat since their opposition to the the receiving country's regime or social cohesion. This condition can lead to the emergence of xenophobic sentiments within the receiving society towards the immigrants (Weiner, 1992: 92-94) However, the conception of security has taken on a new dimension after the Cold War. There is a widespread argument that "states can be made insecure by factors other than the threat of a war". Among these factors is unwanted migration which is a matter of 'high international politics' as a concern for internal security as well as external security. Critical approaches to security, focusing on the role of state and societal actors in associating migration to security, and stressing security of not only states but also individuals, offer a fuller account of migration. Whereas traditional security conception takes migration as a 'real' threat, and fundamentally in relation to state security and 


\section{Security}

national interest. However, for critical security approaches, security is a social construction the meaning of which differs depending on different contexts and social interaction between actors (McDonald, 2008: 61).

For example, securitization concept of the Copenhagen School refers to the 'construction of threat in a discursive manner' (Wæver, 1995: 47). Specifically, securitization is a process in which a securitizing actor pronounces a specific issue or actor to be an existential threat to a referent object. For the Copenhagen School, securitization is carried out by political elites through speech acts (Wæver, 1995: 47). Discursive approaches emphasized that policies and the political significance of events depended heavily on the language through which they are politicized (Huysmans, 2006: 7). In general terms, the securitization of migration, for the Copenhagen School, is an identity related securitization, therefore it invokes such emotions of societies as stability and unity (C.A.S.E. Collective, 2006: 453). However, according to Wæver (Wæver, 1995: 64), the act of securitization may often lead to 'over-securitization', and therefore the creation of 'fear societies'. For the Copenhagen School, this fear of the other creates a context of inclusion and exclusion, as a result of which integration within these societies appears as the elimination of the other (Huysmans, 1995: 60).

In the study of security, the Paris School which has its roots in political theory and sociology of migration and policing in Europe, rather than mainstream international relations (C.A.S.E. Collective, 2006: 446), emphasizes the internal security and its relation to external security rather than international security (Bigo, 2008: 126). Indeed, migration is naturally a cross border security issue, and there is a close relationship between migration and crime, terrorism, unemployment, religious fanaticism, racism, social exclusion and poverty. Therefore, the Paris School favors a widening perspective on security agenda by addressing security not only restricted to survival, but also economic and social dimensions (Bigo, 2008: 13). In this respect, migration can be made into a security issue by identifying four ways (Ceyhan and Tsoukala, 2002). First, from a socioeconomic perspective, migration is linked to unemployment, deterioration of the welfare state, and thus economic insecurity. Second, from a state/military security perspective, migration is associated with loss of sovereignty, borders, internal and external security. Third, from an identity perspective, immigrants are viewed as a threat to receiving societies' national identity. Fourth, from a political perspective, anti-immigrant discourses are used for the cause of facilitating political benefits. In addition to discursive construction of security threat, the Paris School emphasizes the role of professional networks of security agencies and security professionalist as the determinant actors of what a security concern is (C.A.S.E. Collective, 2006: 457). For the Paris School, conceptualization of security is carried out through the capability to manage threats, to control borders, and to define identities at danger by governments because the Paris School treats security as a 'technique of government' (by Foucault, 1994 cited in C.A.S.E. Collective, 2006: 457).

Indeed, insecurity is portrayed as a politically and socially constructed phenomenon Huysmans, 2006: 2). Insecurities differ depending on the nature of the threat and the referent object that is threatened. In this respect, the securitization of immigration or refugees depends on instituting credible claims that they are an important factor endangering the survival of political 
units such as state, nation and/or identity-based social groups. Indeed, as Jef Huysmans argues that domains of insecurity arise from institutional and political reactions to a threat (Huysmans, 2006: 6). Accordingly, discourses and practices representing migration as a threat to social and political integration have become a significant source for mobilizing security rhetoric and institutions. While these security rhetorics and practices contribute to the stratification of social relations, they also increase the exclusive perspectives in society and political life.

Since 1990s, security approaches have increasingly impacted on issues of migration, immigrants and asylum. However, it is difficult to grasp these issues only as a process of securitization in the context of linguistic approach, as advocated by the Copenhagen School. Although speech acts that define migration as a major security threat to Europe have a significant place in securitization of it, routine bureaucratic practices and visual representations in terms of migration play a key role in this process. For example, the Schengen Agreements include migration related issues as a major issue of concern. However, their 'securitization' seemed to result from being listed together with border control, international crime, etc. in an institutional process dominated by security professionals and policing and customs concerns rather than from explicit speech acts defining migration as a major security threat to the EU (Huysmans, 2006: 150). Therefore, the securitization of problems of migration, immigrants and asylum are intertwined by institutional, linguistic and mediatic processes.

\section{Migration, Insecurity and Dilemmas of Europe}

In the post-war period, migration receiving countries in Europe viewed international migration as primarily an economic phenomenon since the growing economies of these industrial countries were willing to welcome immigrants. In the 1950s and the early1960s, Western European countries imported several million workers from North Africa and Southern Europe to meet the labor demands of their rapidly growing economies (Weiner, 1995: 4). Indeed, the migration in the European context was an issue defined in terms of economic development until the 1970s. Therefore, until the mid-1970s, the European Community tended to act in accordance with the migration policy of the United Nations, which favored economic well being of migration receiving states and human rights of immigrants (Weiner, 1995: 158-162). However, Western European countries have established a relationship between security and migration, in accordance with their economic and also societal security concerns since the late 1970 s with the development of a restrictive migration policy (Huysmans, 2000: 751). This was because, as the amount of illegal immigrants seriously increased in the 1970s, economic motivations of receiving states for accepting immigrants became less significant while the economic and societal security of receiving societies became their primary concern.

The Single European Act (SEA) that was signed in 1986 and entered into force in 1987 defined free movement in terms of the abolition of internal border controls (Single European 
Act, Art. 13). Accordingly, the Schengen Agreement of 1985 brought the elimination of border checks among Community members calling for common data bases, exchange of good practices, and a common visa policy between Schengen member countries. The abolishment of internal border controls created the need to strengthen external border controls. As a result, in the 1980s policy debates framed migration largely negatively by playing out three themes: the protection of public order and the preservation of domestic stability, challenges to the welfare state, and questions about multiculturalism and thus the cultural composition of the nation. Migration related issues were increasingly integrated into discourses and policies arranging domains of insecurity (Huysmans, 2006: 68).

With the signing of Maastricht Treaty in 1992, cooperation in justice and home affairs has become a part of integration process of Europe. It addresses the need for interaction between the police, customs, immigration services, and justice ministries of member states. The Maastricht Treaty's Title VI addressed migration as a matter of common interest together with the fight against terrorism, drugs and trafficking and other forms of international crime (European Council, 1992). In this context, the most important institutional change that is brought by Maastricht Treaty is the establishment of EUROPOL that would be operational throughout all Europe about common internal security issues. The enlargement of the EU's authorities in order to embrace the issues such as migration and the establishment of institutional mechanism such EUROPOL emerged partly out of the Schengen Agreements of 1985 and 1990 to coordinate border policy resulting from more open movement of people between EU member states.

With signing of Amsterdam Treaty in 1997, visa, migration, asylum and free mobilization of people became the part of the EU's decision-making process and authority (Ovalı, 2006: 91). Thus, the European Commission gained the ability to propose binding measures to the European Council, and migration and asylum policy were carried into the policy area dealt on a supranational basis. The treaty aimed at promoting societal security in Europe by restricting visa and asylum practices, and it presented illegal immigrants as a threat to the formation of an area of freedom, security and justice.

In the EU framework, the nexus between migration and asylum policy on the one hand and security concerns on the other has become more prominent since the terrorist attacks in the United States on 11 September 2001, in Madrid in 2004, and in London in 2005 (Huysmans, 2006: 1). Until these tragic violent attacks, migration, immigrants and asylum have not always been the main object of the policy initiatives. However, in the context of abusement of asylum procedures by terrorist in order to move into a country, migration, immigrants and asylum become an issue within more broadly defined anti-terrorism policy (Huysmans, 2006: 64). Consequently emergence of "security gap" have accelerated the securitization process of migration (Karanja, 2000: 127). Since then, the relationship between migration and security has been reinforced on the part of migration receiving countries, and the term immigrant has become synonymous with 'suspect' and 'potentially hostile foreigner' (Bigo and Guild, 2005: 66).

In this respect, just after 11 September the attacks, Western governments both American and European have toughened not only external controls but also internal controls of non- 
citizens. For instance, migration policies of the EU are started to be characterized by the constant reinforcement of border controls, the hardening of the clauses of entry as well as of the deportation measures, the declining of the legal status of asylum seekers, the application of migration controls, the imposition of visa issuing and of penalties on carriers transporting illegal immigrants, the strengthening of cooperation with third countries, and the expansion of identity checks within the EU countries' territory (Tsoukala, 2005: 161). In order to institutionalize the border control practice within the EU structure, European Agency for the Management of Operational Cooperation at the External Borders of the Member States of the European Union (FRONTEX) was established in 26 October 2004, and thus, European border management regime was institutionalized (Koca, 2014: 62) The main mission of FRONTEX is to control and prevent irregular immigrants' mobilization in external borders of the EU in order to provide internal security of it.

Increasing border control for the purpose of making it more difficult for immigrants and refugees to enter a country is a strategy of maintaining existing internal order, security and stability from external threats and dangers emameting from "others". That is why, smart border control systems target the "other", not the "us". While potentially dangerous people and groups are subject to strict surveillance, some of them can be taken custody and can be interrogated in order to discover their travel aims. For the 'normalised individuals', these practices would seem to be less of a problem (Bigo, 2011: 31-50). Therefore, emphasizing restrictions and control implies a negative portrayal of groups of immigrants. Common regulations on migration in Western Europe have emphasized the need for restrictions of population flows. There are many more examples of the restrictive and control-oriented imperative that drives European migration policy. Among the most visible are the coordination of visa policy in the Union, the coordination and facilitation of so-called readmission agreements, biometric passports and various databases (Huysmans, 2006: 68). However, such policies and practices help to sustain public expressions of racism and xenophobia in the present political context by intensifying the fear and unease about migration and immigrants. So, irrespective of initiatives to combat racism and xenophobia such as the creation of a European Monitoring Centre on Racism and Xenophobia, the EU is indirectly implicated in the rise of racist and xenophobic reactions to asylum-seekers and immigrants (Huysmans, 2006: 75).

Migration has an obvious potential to lead significant changes in political realm by increasing nationalist attitudes and cultural conflicts in hosting societies and regions. Therefore, it is obvious that there is a close relationship between increasing power of radical right political parties and reactions of people againts immigrants and migration issues in Europe. Indeed, growing xenophobia and hostility against "others" in Western European countries have led to calls for anti-migration to gain electoral success. Indeed, from the 1990 s onwards, the view of migration as a security threat to receiving countries and the consequent tendency towards exclusion of immigrants has gradually strengthened among receiving societies as well as state actors in Europe. The development of a common migration and asylum policy in the EU's institutional framework is presented as an instrument for dealing with the rise of racist, xenophobic and extreme nationalistic practices in Europe (Huysmans, 2006: 76) Thus, the securitization of migration is accompanied the integration process of the EU. 
However, when themigration practices of the EU andits memberstates areclosely considered, they are formulated in order to control these 'threatening' immigrant groups. Discriminative and exclusionary visa policies to these immigrant groups have led to contradictionary policies with human rights and democratic values of the Union (Koca, 2014: 61). While the EU is based on multiculturalism, the revival of extreme nationalism, racism and xenophobic reactions to "others" have a great potential to destabilize the domestic and European political space.

In terms of welfare aspect of the problem, immigrants are considered as illegitimate recipients of socio-economic rights introduced by the EU and its member countires. Curtailing social assistance and access to other social rights for immigrants and asylum-seekers can then be justified as an instrument for limiting the number of applications for asylum and migration (Huysmans, 2006: p.77). Thus, migration and immigrants are also securitized issues in the context of welfare state conception of Europe. Political leaders and parties which are anti-immigrants have growing tendencies to popularize socio-economic aspects of the issue in their political propagandas and programmes. As a result of 2008 global financial crisis, European economies such as Greek, Portuguese, Spanish and Italian were subject to the economic stagnation and its adverse effect on welfare state practices. Financial assistance programmes of the EU for these economies caused to concerns about the European integration. Particularly, rightist and farrightist social movements and political parties have started to make propaganda in terms of empowering of their own nation-states by priviliging preserving national sovereign rights and identities. The growing number migration flows to Europe has been in company with the socioeconomic problems. In this context, for instance, dedicated financial resources to immigrants have been critizised by public and political leaders, and help them to formulate their discourses in the respect of anti-immigrant policies (Mandacı and Özerim, 2013).

Securitizing acts often require the involvement of speeches of politicians, practice of bureaucratic institutions and also media coverage that frame issues such as refugees and immigrants by means of evoking crisis situations, emergencies, enemies and dangers (Huysmans, 2006: p.60). In terms of media that play a key role in the construction of security questions migration, immigrants and asylum are casted in a stereotypical way and emphasized its disrupting consequences (Bigo, 2002: 63-92). They tend to highlight the involvement of immigrants and refugees in violence and criminal activities. Thus, negative representations of migration, immigrants and asylum in media contribute to the intensification of securitization process of them. Charlie Hebdo and Dannish caricature crisis are typical example of the role of media in this process. After the tragic attacks to the Office of Charlie Hebdo and a kosher supermarket in Paris in January 2015, an unprecedented public reaction took place in France in defence of the endangered 'values of the Republic': liberty, equality, fraternity (Fassin, 2015: 3-7). In addition to mobilization of French people, with the participation of political leaders of international community like Mahmoud Abbas, President of Palestinian National Authority and Benjamin Netanjahu, Prime Minister of Israel, these terrorist attacks were protested and stated the importance of inclusive policies for and basic rights and freedoms of every human beings. 
Therefore, degradation of "other" substantially people from Muslim World and/or Third World in speeches of politicians and media coverage like caricatures of the Prophet Muhammed published in Danish newspaper Jyllands-Posten in 2005 leads to subversive effects not only for the innocent Muslim people, but also for other people from different religions. Radical voices from far rightists in Europe and militarized Islamic organizations strongly and effectively use such conditions as a justification for their exclusionary world views. At the end, social cohesion of European society and cosmopolitan policy expactation suffer dramatically due to the segregation of people.

Conversely, current measures taken by the EU and individual member states of it for addressing migration and immigrant issues mostly focus on the results, not reasons of them. However, the real solution for these issues should be searched by regarding the reasons of motivations of people's mobilization. After the end of the Cold War, global developments have led to a perspective that goes beyond the state-centric and military-based security conceptions. With help of this transformation about security concept, new discourse have arisen in order to bring together concepts of development and security.

As a matter of fact, in 2006 the Commissioner for External Relations Benita Ferrero-Waldner explained that 'the philosophy underlying the EU's approach to security is that security can best be attained through development, and development through security. Neither is possible without an adequate level of the other' (Ferrero-Waldner, 2006). And also, human development as a request for an overall security is already the target of much of EU's development agenda. However, people must first be secure from critical and pervasive threats to their vital core, whatever the cause, before the mechanisms of development can take root (Martin and Owen, 2010: 222). Therefore, the EU should pursue efforts in order to end violent conflicts in its surrounding regions by using military and non-military means such as peace-making and peace-building activities. However, it can be said that the EU is rather weak due to its incapability in its foreign policy to respond to the emergency situations (Ağır, 2015: 370). Development problems and violent atmosphere in these regions are the main explanation of reasons of migration problem that the EU faces. Therefore, it can be concluded that the close connection between development and security has important implications on migration and people's mobilization.

Indeed, the EU sought to construct a Euro-Med Region during 1990s to meet its own domestic economic, societal and military security interests. However, this is not to suggest that the members of the EU have adopted a single common approach or that EU policy-makers speak with one voice regarding Middle Eastern issues. On the contrary, EU members do not all share the same sense of urgency or the need to adopt an independent and common European foreign policy towards the Middle East (Bilgin, 2011: 140-141). However, the current distability, disorder and conflictual environment in the Middle East and North Africa constitute detrimental effects to security and stability in the EU (Bilgin, 2011: 141). It seems clear that there is a need for a comprehensive perspective in order to rethink security in Europe against the backdrop of migration from its southern regions, mostly the Middle East and North Africa. 


\section{Conclusion}

In broadening international security agenda of the post-Cold War era, migration, immigrants and asylum have become one of the phenomena in relation to which general sense of insecurity is articulated. The irregular migration becomes a source of insecurity not only for these immigrants, but also for the members of the receiving communities and states by increasing fear and anxiety about this type of human mobility (Bilgiç, 2013: 2). As it is mentioned in European Security Strategy of 2003, the post-Cold War environment is one of increasingly open borders in which the internal and external aspects of security are indissolubly linked, and it is in the European interest have a well-governed borders (European Security Strategy, 2003). In the case of Europe, migration and immigrants are highly politicized an even securitized issues, and they are often discussed in conjunction with their security implications.

The immigrants, refugees and asylum are fixed into a threat to the cultural self-definition of the people in the member states of the EU. Therefore, discourses representing migration as a cultural challenge to social and political integration have become an important source for mobilizing security rhetoric (Huysmans, 2006: 64-73). And also, institutional bureaucratic practices and networks have played a very significant role in the securitization of migration and asylum in the EU (Huysmans, 2006: 121). Under the effects of discoursive, bureuacratic practices and mediatic representations, migration and related issues are regarded as the main reasons of contemporary insecurity in Europe with reflection to politics. However, security of Europe is not only about the defence of the continent from hard security threats, but also requires the ontologically maintainance of European values. It should not be forgotten that normative Europe and its integration model is mostly based on universal values such as human rights, democracy and protection of civil liberties by excluding the memory of xenophobic and racist violence in European societies.

Given Europe has become the destination for the immigrants, this article seeks to analyse the issues of migration, immigrants and asylum from a security studies angle in European context with reference to recent developments and implications to European values such as liberal rights and freedoms, multiculturalism and plurality. In this respect, it is argued that illiberal security policies and practices have led to questioning of pluralism and multiculturalism concepts. Such policies and practices not only privilege the common good of "us", but also cause exclusionary discourses and practices for "other". Under these circumstances, while a political community will be consolidated in the respect of the existence of a common "enemy", multiculturalism and liberal democracy will only be a wish for all people irrespective of their identity origins. Therefore, in order to be able to address the migration problem in a proper way, a cosmopolitan political conception should be dominant that emphasizes cultural plurality rather than differences (Beck, 2002: 17-44). That is why, the question should be asked whether the EU will continue to be an area of freedom, security and justice for all people, or just for Europeans. 


\section{References}

1. Ağır, B. S. (2015) "European Perspective of Human Security: From a Conception to the Reality?". In: Twenty Years of Human Security: Theoretical Foundations and Practical Applications. Belgrade: University of Belgrade and Institut Français de Geopolitique Universite Paris 8, p. 365-374.

2. Beck, U. (2002) “The Cosmopolitan Society and Its Enemies” in: Theory, Culture and Society. Vol. 19, p. 17-44.

3. Bigo, D. (2001) "Migration and Security". In: Controlling a New Migration World. London: Routledge, p. 121-189.

4. Bigo, D. (2008) "International Political Sociology". In: Security Studies: An Introduction. London: Routledge, p. 116-129.

5. Bigo. D. (2011) "Freedom and Speed in Enlarged Borderzones". In: The Contested Politics of Mobility: Borderzones and Irregularity. London: Routledge, p. 31-50.

6. Bigo, D. and Guild, E. (2005) Controlling Frontiers: Free Movement Into and Within Europe. Aldershot: Asgate.

7. Bilgiç, A. (2013) Rethinking Security in the Age of Migration: Trust and Emancipation in Europe. London: Routledge.

8. Bilgin, P. (2005) Regional Security in the Middle East: A Critical Perspective. London: Routledge.

9. C.A.S.E. Collective. (2006) "Critical Approaches to Security in Europe: A Networked Manifesto" in: Security Dialogue. Vol. 37, p. 443-487.

10. Ceyhan, A. and Tsoukala, A. (2002) "The Securitization of Migration in Western Societies: Ambivalent Discourses and Policies" in: Alternatives. Vol. 27, p. 21-39.

11. European Council. (1992) "Treaty of Maastricht on European Union". http://eurlex.europa. eu/en/treaties/dat/11992M/htm/11992M.html (visited on 28.03.2018).

12. European Council. (2003) "European Security Strategy, A Secure Europe in a Better World". http://www.consilium.europa.eu/uedocs/cmsUpload/78367.pdf (visited on 10.04.2018).

13. Faist, T. (2002) "International Migration and Security before and after September 11, 2001" in: International Migration Review. Vol. 36, p. 7-14.

14. Fassin, D. (2015) "In the name of the Republic: Untimely meditations on the aftermath of the Charlie Hebdo attack" in: Anthropology Today. Vol. 31, p. 3-7.

15. Ferrero-Waldner, B. (2006) Protecting Europe's Security. Speech to Conference on 'Protecting Europe: Policies for Enhancing Security in the European Union', Brussels, http://europa.eu/rapid/press-release_SPEECH-06-331_en.htm (visited on 20.03.2018).

16. Huysmans, J. (2006) The Politics of Insecurity, Fear, Migration and Asylum in the EU. London: Routledge.

17. Huysmans, J. (2000) "The European Union and the Securitization of Migration" in: Journal of Common Market Studies. Vol. 38, p. 751-777. 


\section{Security}

18. Huysmans, J. (1995) "Migrants as a Security Problem: Dangers of Securitizing Societal Issues". In: Migration and European Integration: The Dynamics of Inclusion and Exclusion. London: Pinter, p. 53-72.

19. Karanja, S. K. (2000) "The Schengen Co-operation: Consequences for the Right of EU Citizens" in: Mennesker og rettigheter Årgang. Vol. 18, p. 215-222.

20. Koca, B. T. (2014) "Biyopolitika, Güvenlik ve FRONTEX'in Türkiye-Yunanistan Sınırındaki Rolü" in: Cöç Dergisi. Vol. 1, p. 57-76.

21. Mandacı, N. and Özerim, G. (2013) “Uluslararası Göçlerin Bir Güvenlik Konusuna Dönüşümü: Avrupa'da Radikal Sağ Partiler ve Göçün Güvenlikleştirilmesi" in: Uluslararası Illişkiler. Vol. 10, p. 105-130.

22. Martin, M. and Owen, T. (2010) "The Second Generation of Human Security - Lessons from the UN and EU Experience" in: International Affairs. Vol. 86, p. 211-224.

23. McDonald, M. (2008) "Constructivism". In: Security Studies: An Introduction. London: Routledge, p. 59-72.

24. Ovalı, Ş. (2006) "AB'nin Terörizmle Mücadele Politikasındaki Dönüşüm: 11 Eylül ve Madrid Saldıılarının Etkileri" in: Ankara Avrupa Çalışmaları Dergisi. Vol. 5, p. 77-102.

25. Single European Act. (1987) Official Journal of the European Communities, http://eur-lex. europa.eu/resource.html?uri=cellar:a519205f-924a-4978-96a2-b9af8a598b85.0004.02/ DOC_1\&format=PDF (visited on 25.03.2018).

26. Tsoukala, A. (2005) "Looking at Migrants as Enemies". In: Controlling Frontiers: Free Movement into and within Europe. Aldershot: Ashgate Publishing, p. 161-190.

27. Wæver, 0., Buzan, B., Kelstrup, M. and Lemaitre, P. (1993) Identity, Migration and the New Security Agenda in Europe. New York: St. Martin Press.

28. Wæver, 0. (1995) "Securitization and Desecuritization". In: On Security. New York: Columbia University Press, p. 46-86.

29. Weiner, M. (1995) The Global Migration Crisis. New York: HarperCollins Publishers.

30. Weiner, M. (1992) "Security, Stability, and International Migration" in: International Security. Vol. 17, p. 91-126. 